\title{
Demographic dynamics, governance and the attainment of democratic development: The case of Nigeria
}

\author{
Matthew Egharevba \\ Department of Sociology, Covenant University \\ Sango-Otta, Ogun State \\ Nigeria
}

\begin{abstract}
The treatise on demography, democratic governance and development issue is an inclusive one that emphasizes the need to create a social world for promoting people's quality of life. Today, the measurement of development as succinctly depicted by the 2000 to 2015 Millennium Development Goals (MDGs) and Human Development Index (HDI) goes beyond the use of economic growth, per capita income, to include how the benefits of that growth and income is widely distributed to expand the people's choice and capability to raise levels of living and enhance material well-being. The paper opines that the challenge of development in Nigeria is not its population size and/or resource endowments, but poor resource management and politicization of development agendas by the 'leadership' and its inability to holistically incorporate population issues and dynamics such as reproductive healthcare, education and employment creation in its development strategies targeted at poverty reduction. As an exploratory study, the paper utilized secondary sources of data collection which include materials from international development institutions such as the UNDP, World Bank, government reports, journals and textbooks in gathering information for the study. The data was examined using the political economy theory of development, the elite theory and content analysis tool to establish the connection among population, development and democratic governance. The paper's discussion and findings indicate that the political leaders and policy makers have consistently failed to generate and adopt valid/reliable demographic data upon which appropriate policy interventions are framed to address human centred development objectives. The paper showed that Nigeria's socioeconommic development policies are not all inclusive, just, equitable, pro-poor, and one that empower the people with human centred rights to access basic life sustaining goods such as food, shelter, protection, health, and better education that will enhance their material well-being and self esteem. The paper conclude with the statement that the leadership must exercise the political will to invest massively in human capital development for Nigeria to achieve the status of a democratic developmental state and deliver the benefits of demographic dividend.
\end{abstract}

Keywords: Development, Governance, Well-being, Demography, Census, Democracy.

\section{Introduction}

The multi-disciplinary nature of the problems related to human population and development has made it expedient that the topic is studied from many angles (Kitching, 1982). The current discourse underlying the linkages amongst demography, democratic governance and development is significant as it centers on the goal of advancing the quality of life of humanity. People represent the real asset of a nation and for their potentials to be fully harnessed and productively so; there is the need for government at all levels to invest massively in the provision of education, healthcare, job creation and basic infrastructure that will enhance the well-being of the people (Egharevba and Chiazor, 2013). This investment in human and social capital has a greater likelihood of guaranteeing a massive reduction in poverty, communicable diseases, malnutrition, servitude, oppression, ignorance, uneven income distribution, and human misery which underscore the core values of development-sustenance, self-esteem and freedom (Goulet,197।:23; Ersson and Lane, 1996:64-65; Sen, 1999:4; Todaro and Smith, 20II:15). Similarly, human and socioeconomic centred rights cannot be fully secured and realized other than through a viable political system where public resources are effectively utilized to promote the well-being of the people. Thus, successful development thrives better in an enabling environment that allow for social and political stability and where governance system is responsible for meeting the needs of the people (UNDP 2002:5). Therefore, the goal of democratic development represents the protection of human rights, promoting

http://aps.journals.ac.za 
wider participation in the institutions, rules and procedures that affect people's lives including achieving equitable economic and social outcomes (Adedeji, 2006; Adekola, 2010; Chiazor and Egharevba, 2013). This realism aligns with the words of Mark Malloch-Brown in the forward of the Human Development 2002 Report:

That politics is as important to successful development as economics. Sustained poverty reduction requires economic growth-but it also requires that the poor have political power. And the best way to achieve that in a manner consistent with human development objectives is by building strong and deep forms of democratic governance at all levels of society.

Thus, any democratic development system is deemed meaningful when underlined by the principles of openness, representation, accountability and protection of individual and group rights (World Bank, 1989:60-6I; Kaufmann, Kraay and Mastruzzi, 2005). The same can be said of the demographic transition and transformation of nations which are triggered by fertility rates, mortality, rural-urban migration, urbanization, population density and composition etcetera which have strong policy implications for development (Fausta and Silvani, 2016; Grace and Andrian, 2016). In 201 I, the world's population reached 7 billion, of which 855 million are living in the world's Least Developed Countries (LDCs). Most LDCs confront large challenges in achieving internationally agreed development goals, including the Millennium Development Goals (MDGs) (UNFPA, 20I2). The LDCs are lagging far behind other developing countries in reducing infant, child and maternal mortality, adolescent pregnancies and HIV/AIDS prevalence due to limited access to reproductive health and high unmet need for family planning services which contribute to high levels of fertility (United Nations, 20/0c). Besides, high population growth represent one of the key factor that affect the capacity of LDCs to catch up with the income levels of the more advanced developing countries on a sustainable basis. Between 2005 and 2010 , the average fertility rate of Less Developed Countries was $4.4 \%$ compared with 2.5 in other developing countries, and the average population growth was $2.3 \%$ compared with 1.2 in other developing countries (UNFPA, 20I2). Over the next forty years, the working age population in the LDCs will increase by about 15 million per year. This will raise the stakes in poverty reduction efforts, including those efforts aimed at raising household incomes and creating employment as well as increase food security, combat hunger and promote sustainable development. The rapid expansion of the population in LDCs makes it more difficult for countries to increase, and indeed maintain, per capita spending on essential social services.

A detailed look at the global demographic transition show that Africa is at the centre of it all. Africa remains the fastest growing continent and its rapid growth is shifting global population balance. Africa's population is rising rapidly and will most likely double its number by 2050 (UN 2009 World population Prospects). With over a billion people today, it is projected that the population in Africa could hit the 2 billion mark in 2050 . With this rapidly on-going demographic transition, pressures are been placed on governments to improve their socioeconomic development performance in terms of delivering better infrastructure, education, healthcare, job opportunities, food, water, sanitation and security for the people (Timmer, 2008). Today, development scholars and institutions places so much emphasis on education, health, social inclusion and empowerment of people as the essence of development and have referred to countries with high levels of income but poor health and education standards as cases of 'growth without development' (William, 2003). Population growth increases density and together with rural-urban migration creates higher urban agglomeration which places a demand on countries to create a sustainable economic development that can tackle population challenges such as lack of food, water, poverty, unemployment, infrastructure, insecurity and inequality. All across developing countries over time, there is a strong inverse relationship between fertility and per capita income, fertility and life expectancy- two common indicators of well-being (Population Reference Bureau and Population and Economic Development Linkages, 2007).

Thus, an examination of the population dynamics in Nigeria since the return to civilian rule in 1999 paints a very dismal picture of government lack of capacity and failure to provide basic life sustaining necessities such as qualitative education, healthcare, shelter and food security for its people in order to help them escape the incidence of poverty and inequality. Available data from the Nigerian Bureau of Statistics (NBS) (20I3) showed that more than 70\% of the population in Nigeria live below the poverty line of US\$ 1.25 dollar per day (specifically $1 / 2$ million out of 170 million live in relative poverty), infant and child mortality rate is one of the highest in world (75 and 88 per 1,000 live birth), under five mortality is 157 per 1,000 live birth, maternal mortality is 545 deaths per 100,000 live births, electricity consumption is 50 percent, access to improved water is 56 percent, improved toilet facilities is 27 percent (NDHS, 2008) and the gap between the rich and the poor in terms of income 
inequality (moved from 0.429 in 2004 to 0.447 in 2010) continues to widen, in spite of its huge natural and material resources, including the projection that the economy is growing at $\mathbf{7 . 7}$ per cent annually in the last decade.

These issues raise concern about the form of governance vis-à-vis the economic and social policies that exists in Nigeria since the return to civilian rule in 1999, and how it has impacted on the quality of life of the people. Given the implementation of neoliberal economic policy in the country since the 1980s, the level of economic development has not been able to catch up with the massive population growth, and this has resulted in the increasing number of persons living in poverty as a result of lack of access to basic needs, infrastructure, freedom, education, healthcare or employment (UNCTAD, 2008; World Bank, 2009). Poor families seem to face demographic cum-income-trap as poverty in the parent's generation promotes higher fertility which is associated with inequality in the next generation. Thus, the connection between demographic changes and inequality becomes evident when government is unable to deliver on the provision of improved nutrition, public health interventions related to water and sanitation, education, healthcare which ultimately affects the general well-being of individuals and society. Thus, increases in the infant, child and maternal mortality of a country reflect the state of nation's socioeconomic development and addressing these challenges becomes an important policy concerns (UNDP, 2007). According to the 2013 National Demographic Health Survey (NDHS) report, the country has a total fertility rate of $5.5 \%$, infant mortality rate is 69 deaths per 1,000 live births and under-five mortality is 128 deaths per 1,000 live births. The country today is far from realizing the development targets enunciated in the Millennium Development Goals (MDGs) which reaffirmed the 1994 International Conference on Population and Development (ICPD) goal of nations delivering human rights based development. This insufficient progress is strongly related to many factors ranging from corruption, weak governance institutions, bad governance, decayed infrastructure and social services, and poor integration of population issues into development strategies. It is the need to address these concerns that necessitate this study which is to interrogate the reasons that underline the lack of incorporation of population dynamics in development agendas in less developed countries using the case of Nigeria and the consequences that this omission and inactions have for poverty reduction efforts and reproductive health strategies. This is very critical as enlarging the choices and opportunities enjoyed by people can add up to a major demographic change, and in turn have a positive impact at the individual, community as well as the country level in reaping the fruits of demographic dividend. In order to carry out this study, the paper will be structured into five sections. Following the introduction is Section two which looks at the concept of demography and its role in promoting development. Section three examines the subject of governance, democracy and development and their linkage with population matters. Section four provide the theoretical base for examining the relationship among population, governance and development and the consequences it holds for the deepening of democratic development in Nigeria. Sections five ends with the conclusion.

\section{Conceptual understanding of demography}

Census represents an indispensable data base required for measuring the physical and social wellbeing of people in a country. It also provides a channel for the estimation of vital socioeconomic indicators of human development and economic policies of government (NPC, 2004). Demography as a discipline helps ensure the attainment of these laudable goals. It involves the study of population and devising means for improving the quality of people's lives (Macionis, 200I:567; Rockefeller, 1952). It also deals with the analysis of population size, its composition, determinants and consequences of these changes on society's socioeconomic development. While demographers are not only interested in numbers and management of population growth, they also generate evidence based data for policy actions through a more comprehensive description of population issues which are central to development. Conversely, a lack of accurate, reliable and consistent data on the well-being of the population is not only detrimental to policy making, but also hamper the comprehensive understanding and broad measurement of development progress of a country.

Consequently, the provision of accurate demographic measures relating to birth rate, death rate, life expectancy level, literacy rate, health care, child/infant mortality, maternal mortality, calorie intake, sanitation and housing are important for understanding the demographic change and the unfolding of the demographic situation, which helps to determine the progress of economic development of nations, including monitoring the MDGs and other development indicators. Thus, demographic data mirror the performance of government of nations in addressing the basic socioeconomic needs of its citizens for improved standard of living. It also provide records to identify the challenges of human development, pinpoint areas where there are 
progress, so that governments are better informed and equipped with facts to make informed decisions and implement the right mix of policy interventions toward tackling issues of poverty, health challenges, inadequate infrastructure, poor sanitation, unemployment and inequality within the framework of available resources. Likewise, any negative change in the demographics of the people paints a straggling drop in the quality of life which can be attributable to many factors such as poor governance and ineffective policies.

Thus, a look at issues relating to the Nigeria's demographics reveal a lot of areas where government attention has not been robust enough in bringing about improvement in the standard of living of the citizenry. These areas include the state of wellbeing of the people as shown in the annual UNDP Human Development Index (HDI), which is a composite measurement of school enrolment, literacy, infant mortality, life expectancy and income (Handelman, 2006: 6). Other issues include the age distribution of the population, migration (ruralurban), popular participation in governance, gender inequality and reproductive health matters. For instance, an expanded educational system in a country does offer the populace additional opportunities by raising their literacy levels; gives them room for earning better income and improved living conditions while also creating more egalitarian values. Besides, increased education and literacy expand mass political participation and increase government accountability to the governed. Similarly, an educated workforce contribute to higher labour productivity at all levels It is therefore, not a surprise that a higher literacy rate has been found to be one of the most crucial prerequisites for democratic government throughout the world and a major tool for economic modernization (Axel, 1992). However, changes in population composition also affect the demand and supply of labour and gender issues which are key determinants of population growth and development.

Furthermore, information on the age and sex distribution of the population brings to the front burner issues that concern youth and women empowerment. For instance, a country's age structure is affected by the rates of change that occur across age groups on the measure of fertility and mortality. As such, the "youth bulge" and the rapid growth of the elderly population relative to the working age population are two key structures that shape development concerns in this century. Thus, massive investments in education and health needs of persons within the 15 to 54 years bracket have important implications for the state to reap the benefit of demographic dividend. The effect of demographic dividend is realized through the proportion of the population in the labour force (quantity), the education and technical skills of the labour force (quality) and the opportunities available to workers to use their skills productively (Anrudh, 2008).

Thus, the youth bulge of a nation represents both risks and opportunities. Just as the baby boom stretches the resources required for ante-natal care and primary education; a surge in the absolute number of youth create pressure on the services used by them-land, education, infrastructure, apprenticeships, and other entry level workforce positions. In situations where large cohorts of youth can be productively absorbed into the labour force, the youth bulge can create a 'demographic window of opportunity' which may yield a high volume of economic outputs relative to the dependent costs of a large elderly population. Be that as it may, circumstances exists in most developing countries such as Nigeria where the economy in spite of experiencing 'positive economic growth' is unable to absorb large number of youths ointo the labour force which may be attributed to misguided economic policies, corruption and poor leadership (World Bank Commission on Growth and Development, 2008). In this circumstance the youth bulge threatens to exacerbate forces contributing to political, economic, and social instability, and serve as engine for external migration resulting in brain drain, child and women trafficking that has become a challenge in Nigeria and other developing countries.

Also, the gender question has also raised the fundamental issue in assessing key development goals and objectives of nations. Women issues constitutes a critical element in determining and controlling the population growth of a nation even though population increase at the national and global levels are mostly caused by a decrease in mortality and not necessarily by an increase in fertility (Anrudh, op cit). Therefore, putting women issues on the front burner of development should be a key policy decision if the drive by any country to develop a population or people with the capacity to lead a socially and productive life is to be realized. Given the size of female population composition in Nigeria which is $\mathbf{5 0}$ percent or more, women's role in driving the modernization process of the nation cannot be wished away. For instance, most of the persons who work in the agricultural and the informal sector are women; they are saddled with the responsibility of child bearing, nurturing, household chores as well as engage in formal employment amongst other activities. Yet, available evidence reveals that women are mostly discriminated against in all spheres of life, as many of them are concentrated in certain 
occupations and faces barriers toward entering others such as politics and leadership where they are underrepresented, including having little influence and control over economic resources and a persistent cultural practice of male dominance. Other forms of injustices include forced female genital circumcision, domestic violence, sexual abuse, assault, divorce laws that are biased against women, barriers to seeking credit facilities, access to land ownership and inheritance rights (Egharevba and Chiazor, 2013).

These gender gaps impact many important facets of political and economic life just as they undermine the social and economic rights of women and young girls, including their socioeconomic and political contributions to society. Thus, incorporating gender perspectives in policy-making and adoption of gender inclusive approaches in the framing and implementation of development-related goals should be seen as the key to attaining sustainable development (OECD, 1999:15; UN 2006:15). This importance is evident in the world's governments' adoption of gender equality and women's empowerment as the third Millennium Development Goal target and the subsequent adoption in the current Sustainable Development Goals (SDGs) initiative. Therefore, empowering women with knowledge and skills becomes an indispensable tool for advancing development and reducing poverty. From the above discourse, it is apparent that policy planners, national government officials, and international development institutions cannot afford to ignore the impact of demographic trends and indicators on the achievement of major development goals, including poverty reduction, health, security and provision of public services and infrastructure (United Nations Economic and Social Council, 1996). Thus, the degree to which these issues are addressed in order to advance the standards of living of the people goes a long way to show strong government commitment to social welfare programs and the share of the country's economic resources that is invested in education, health care, infrastructure and sanitation (Egharevba, Iruonagbe, Azuh and Chiazor, 2016).

Be that as it may, a look at the population question in Nigeria has always revolves around the issue of numbers, specifically with respect to how many we really are at any point in time? The history of Nigerian census dates back as far as 1886 when the first organized attempt was made to enumerate the people of Lagos area. Since 1886, there have been 15 documented attempts to enumerate the population of either part or entire territory of Nigeria. The earliest attempts were through conjectural estimates or through tax returns. These were followed by partial census and later complete national censuses (Edewor, 2008). Since the first census was conducted, each census figure was disputed by one segment or the other in the country (Oyekanmi, 1992). There were and still are accusations of either undercount of some ethnic groups or over count of some otherssss groups. Rather than seeing census as a scientific/technical exercise it has been regarded as a political issue in the nation. It is obvious that the last censuses in the country (199I and 2006) have been accepted albeit with some reservations from certain stakeholders (Oyekanmi and Ogunlade, 2008). Nnorom and Kunnuli (2006) argue that ethnic pluralism in the country and the struggle for numerical supremacy negatively impact on the census process and population statistics, which are believed to be manipulated for political purposes and making the figures needed for planning unreliable. This reservation about the negative effect of unreliable population figures on development in Nigeria has also been expressed by several scholars especially as it relate to the achievement of development objectives in the country, including the MDGs (Oyekanmi, 2008; Nnorom, 2008; Oyefara, 2008). For political reasons, the population density shows that Nigeria is about the only country in the world which records a greater population in the states located in the savannah than those located in the forest zone.

In the same light, given the census statistics and other population information gathered from sources such as vital statistics, sample surveys especially demographic health surveys (DHS) and migration in Nigeria, the general picture one gets is that of a country with rapid population increase of 3.18 percent annual growth rate and a young age structure where about 44 percent of the population are below I5 years of age (NPC, 2009). This implies that much of the resources of the nation are devoted towards consumption activities like education, training for capacity building and provision of social services for a large proportion of the population who are not in the labour force and cannot contribute to production of goods and services. It is in this light that population may be regarded as a burden on the nation as they constitute more of consumers than producers. In a plural state like Nigeria, where the constituent parts see their proportions of the total population as their means of survival, checking population growth is usually very difficult. Two population policies have been enacted in Nigeria (1988 and 2003) with the aim of curbing population growth rate and improving the welfare of the populace. The state of war for numerical supremacy as well as other reasons has made these policies inactive and the targets 
unattainable (Obono, 2002; Nnorom and Kunnuji, 2006).

Imperative of democracy, governance and development for population advancement

The pursuit of advancing the quality of life of people in a given society will require the existence of a responsive, transparent, representative and accountable government that can effectively tackle the challenges of poverty, inequality, unemployment; promote economic growth and human development. Today, underlying the litany of Africa's development problems is a crisis of governance, the deteriorating quality of government, epitomized by bureaucratic obstruction, pervasive rent-seeking, weak judicial systems and arbitrary decision-making which seriously hampers sociopolitical and economic development in the continent (World Bank 1989:6061). This condition derive from the increasing incidence of massive corruption among government officials and political elite, flagrant misuse of executive powers, lack of transparency, accountability, absence of openness in policy formulation, absence of people's participation in issues that directly impact on their well-being as well as the poor defense, protection and preservation of individual and group rights. Thus, to fully appreciate the current state of Nigeria's demographic dynamics and issues associated with it, it is essential to examine the role of democracy, governance and development in advancing population development.

Development entails a condition in which people can meet their basic needs for existence and live an improved quality of life. To achieve this goal, there is the need to institutionalize a social system of governance that manages and channel resources and people effectively. Here, people must be seen to be the agent, means and ends of development- that is their interest and well-being is the measure of all things; the supreme law of development. Generally, development can be viewed from political, economic and social dimensions. Accordingly, Sen (1999:3) provides a useful theoretical and empirical formulation of development "as an integrated process of expansion of substantive freedoms that connect with one another". He identified five distinctive types of freedom, seen in an instrumental perspective as " $(I)$ political freedoms, (2) economic facilities, (3) social opportunities, (4) transparency guarantees and (5) protective security; concluding that, freedoms are not the primary ends of development, they are also among its principal means." He further opines that, focusing on human freedoms contrasts with narrower views of development, such as identifying development with the growth of Gross National Product (GNP), or with the rise in personal incomes, or with industrialization or technological advance, or with social modernization. While growth of GNP or of individual incomes can, of course, be an important means to expanding the freedoms enjoyed by members of the society, freedom depends on other determinants such as social and economic arrangements (for example facilities for education and health care) as well as political and civil rights (which includes the liberty to participate in public discussion and scrutiny (Sen, op cit).

Todaro (2000) conceptualizes development as a multidimensional process involving major changes in social structures, popular attitudes, and national institutions, as well as the acceleration of economic growth, the reduction of inequality and the eradication of absolute poverty. In the context of this paper, development is conceived as a conscious accelerations of economic, political, social, educational and technological growth of Nigeria through effecting, consistent, progressive, and enduring policies of government. Government represents the formal organization that directs the political, economic and social life of a society. As such, government's socioeconomic policy helps determine to a great extent the share of the country's resources that is invested in education, health care, infrastructure and sanitation- that is how much economic growth translates into social development. Thus, when a country's social indicators are higher than its per capita income, it does suggest a strong government commitment to health, education and economic equity, while a reversal indicates government failure to translate adequately its scarce economic resources into an improved quality of life. This is significant as reports from the UNDP Human Development Index (HDI) the measure of a country's living standards, have revealed that poor public policy formulation and implementation has adversely affected social conditions in the Third World (Handelman, op cit, 4). Thus, for effective and progressive development in all spheres of our national life to exist, it must evolve from a truly democratic political system that places value on protection and promotion of human rights and fundamental freedoms. The association of development with democracy is borne out of the position that democracy ensures accountability of the ruler to the ruled with the result that rulers are motivated to allocate resources effectively and productively in order to be allowed to stay in power. As for Africa, this fact is given credence to following the obvious failure of most authoritarian regimes to stimulate economic growth and improve the quality of life of the citizenry (Grossman and Noh, 1988, 
African Union, 1990, World Bank, 1990, Huntington, 1991; Ojo, 2005).

Democracy, therefore, as a concept is intricately linked to the demands of equality, 'one person one equal vote.' As it is well known, democracy according to the Ancient Greek means 'rule by the people. At the very minimum, democracy denotes the rights of the people to choose their own government through institutionalized multiparty system and periodic secret ballots (Adedeji, 2006). Ideally, democracy entails individual participation in the decisions that affects one's life. For democracy to exist in a given society, it must encompasses the following basic components: honest and competitive elections in which opposition have a realistic chance of winning; universal adult suffrage, widespread opportunities for participation, free and open mass media; and government respect for human rights, including minority rights (Hadenius, 1992; Dreze and Sen, 2002:24). Presently, it is universally accepted that democracy requires more than elections and majority rule to be sustainable. Underlying the value of democracy is individual dignity, equality of all people before the law and of opportunities in all aspects of life- social, educational, economic as well as political, and encompassing employment, housing, recreation. In all, for democracy to be meaningful, it must be underlined by the principles of openness, representation, accountability, transparency and the defense, protection and preservation of individual and group rights (Kaufmann et al, 2005; Adekola, 2010). Related to the concept of democracy is participation which has become central to contemporary development thinking. Procedurally, popular participation is achieved through majority rule and the respect of minorities. It is valued as an opportunity for individual self development, and that citizen's participation in public affairs is based not upon the policy outcomes, but on the idea that that such involvement is essential to the full development of human capabilities (Fukuyama, 1992).

Accordingly, Blackburn (1998:2) defined participation as the commitment to help create conditions which can lead to a significant empowerment of those who at present have little control over forces that condition their lives. The World Bank (200I:3) describe participation as a process through which stakeholders influence and share control over development initiatives as well as the decisions and resources that affect them. The World Bank's view on participation has essentially emphasized its instrumental role in poverty alleviation. Here, the ultimate goal of participation is increased accountability, transparency, and efficiency of those governance structures in promoting development and reducing poverty. It is within this context that one begins to examine the concept of governance, which deals with the process through which group decision-making are made to address shared problems. Governance describes the way in which a group, organization or an institution chooses to engage in certain activities backed by goals shared by its constituents. It refers to the exercise of power through a country's economic, social and political institutions in which institutions represent the organizational rules and routines, formal laws, and informal norms that together shape the incentives of public- makers, overseers, and providers of public services (UNDP, 2007). It is not the same as government even though both concepts deals with intentional behaviour on the part of a group, organizations or institutions and its members to achieve certain goals. Governments have the formal authority to act; they also have the political power to enforce compliance with their activities, rules and policies (see Carrington et al, 2008).

The Human Development Report (2002:6) sees 'effective governance' as a 'set of principles and core values that allow poor people to gain power through participation while protecting them from arbitrary, unaccountable actions in their lives by governments, multinationals and other forces. As such, governance means ensuring that institutions and power are structured and distributed in a way that gives real voice and space to poor people and creates mechanisms through which the powerful can be held accountable for their actions'. On the other hand, democratic governance, therefore, exists when the authority of the government is based on the will of the people and responsive to them. It is open when, democratic institutions allow full participation in public affairs and when human rights protections guarantees the right to speak, assemble and dissent; when government institutions are pro-poor and promote sustainable development of all citizens.

While many Third World countries are becoming democratic today, the quality of governance is attracting more and more attention within and among countries, and as such, good governance has become an important criterion for determining a country's credibility in the practice of democracy. Thus, good governance must promote equity, participation, pluralism, transparency, accountability and the rule of law. Governance is good if it support a society in which people can expand their choices in the way they live; promotes freedom from poverty, deprivation, fear and violence, and sustain women advancement. Governance must be rooted in these principles in order to move society toward greater human development through poverty eradication, environmental protection and regeneration, gender equality and sustainable livelihoods. In practice, these 
principles translate into certain tangible things, such as; free, fair and frequent elections, a representative legislature that makes laws and provide oversight over the activities of the executive; and an independent judiciary that interpret laws. Besides, good governance also decentralizes authority and resources to local governments to give citizens a greater role in governance. Finally, good governance ensures that civil society plays an active role in setting priorities, making the needs of the most vulnerable people in society known.

Even as good governance takes hold in most developing societies, challenges to it sustainability also emerge. The greatest threats to good governance today comes from corruption, poverty and violence, all of which undermine transparency, security, participation, accountability and fundamental freedoms. It is within this framework that one can begin to interrogate the relationship between population, development and governance. Population issues leans more on the demographic and sociological aspects and how these interact with forces that bring about or inhibit development in societies. Population changes occur through the interaction of fertility, mortality and migration (Oyekanmi, 1999a). These three major components of human population helps us to know the number of people in a defined territory, their characteristics or composition, rate of growth or changes in number, geographic distribution as well as the nature and effects of their activities which may have repercussions on the welfare of people now and in the future.

Population growth which result from fertility minus mortality or plus migration can have both negative and positive consequences for the development of a country. Negative growth would occur when there is a decrease in the number of people whereby mortality and emigration outnumber fertility and immigration. Such situations can occur in cases of conflicts or war in which a lot of people are forced to move out of their countries as well as epidemics that cause considerable loss of lives such as it occurred in Liberia, Sierra Leone, and Rwanda. However, the occurrence of positive growth implies that there is an increase in the number of people through the excess of fertility and immigration over mortality and emigration. This is the case of Nigeria, the United States of America, and United Kingdom. In developing regions, attention has been on the countries with rapid population growth and the debates on whether population would or would not hinder their development. In general, attention has been focused on the mal-effect of rapid growth of population on development especially in the developing countries; while in the developed countries there has been much consideration of ageing population and paucity of youth to reinvigorate the societies (UN, 2009:8).

Be that as it may, planners and policy makers often use measurements of fertility and mortality as quick indicators of change in population to gauge how their variations affect development parameters. In countries where censuses are undertaken at regular intervals and vital statistics on births and deaths are available on a continuous basis there is usually no argument about the validity of data on population which can be used as inputs for developmental planning purposes. Similarly, it is possible to make projections of population for a future designated time if one has the needed parameters especially the annual growth rate of the population and time interval. The most used projection is that of the doubling of the population which is computed as 70 divided by the annual growth rate. Hence for a country like Nigeria with an annual growth rate of population estimated at $3.18 \%$ (NPC, 2009), the population doubling time is $70 / 3.18=22.08$ years. In other words, the population of Nigeria which was 140 million according to the 2006 national population and housing census (NPC, 2009) is expected to be about 280 million by the year 2028 .

However, the critical question that often arises with the issue of population growth in Nigeria is whether the standard of living of the people can be improved on between now and 2028 if measured through per capita income; provision of health and social services, such as percent of population that are literate, percent of population gainfully employed, percent of births that occur where mothers have qualified medical personnel in attendance, reduction in maternal mortality rate, infant mortality rate and reduction in percent of population who have HIV/AIDS. These and other issues have been spelt out in the Millennium Development Goals with 2015 set as the target period where the goals should have been achieved. But we know that given the current level of development in Nigeria, these goals appear to be far from realization. At present, the capital budgets of all tiers of government is far less than the recurrent budgets and this has serious implication on the quality of life of the people with respect to accessing the basic necessities of existence. As of mid-20II only 39 percent of the population are attended to by skilled medical personnel. Maternal deaths per 100,000 were 840 in 2008, the percentage of adults aged I5-49 years with HIV/AIDS in 2009 were 4.4 among women and 2.9 among males. The proportion of the population that was gainfully employed among the population aged 15+ years was generally low as shown by the fact that only 39 percent of females and 77 percent of males in 
these ages were economically active (PRB, 20II). Presently it is estimated that about 70 percent of the Nigerian populace live on less than US\$ I.25 dollar per day. Moreover, 35.9 percent of the population aged 6 years and above have no formal education and only 15.24 percent of the households reside in houses where the toilet has water closet and 43.23 percent use pit latrine and about 19.79 percent of households reside in structures that use nearby bush/beach/fields as toilet (NPC, 2009:275). This would have negative implications for the health of the people. The available evidence indicates that the level of poverty as well as unemployment among the people is higher than what it was in the 1970s. So the question which then arises is whether population growth is impeding development of Nigeria or can the population when properly harnessed contribute to the development of the country.

Demographic reports provide the platform for us to gauge the performance of government and its socioeconomic policy in terms of delivering sustainable development outcomes, including better service delivering across sectors like health, education, urban planning, agriculture and effective/efficient management of natural resource revenues. It points to us the degree to which government focuses its priorities and distribution decisions on meeting basic human needs and placing primary emphasis on reducing poverty. Likewise, it also enable us to interrogate whether democracy does deliver on the provision of economic justice such as providing access to meeting basis needs like food, shelter, health care, and housing. However, scholars have raised question has been raised as to the relation between democracy and economic development and whether democratization is conducive to development (Emmerson, 20I2). Be that as it may, examining the relationship between democratic legitimacy and quality of democracy is a complex one. The conventional wisdom holds that popular commitment to democratic regime will gain strength if the characteristics as well as the performance of the democratic regime are perceived to be superior to the old or authoritarian regime on some important indicators of good governance such as political liberty, equality, rule of law, accountability, transparency, and responsiveness. On the other hand, symptoms of bad governance, such as rampant corruption, electoral fraud, massive poverty, intra and inter party ranglings, and protracted gridlock, erode people's trust in democratic institutions. In establishing a nexus between democracy, governance and economic development, there exist two broad contradictory trends which have remain pertinent in the context of this dialogue for years (Omotola, 2006). One side posits a correlation between democracy and economic growth, another sees a trade-off between democratization and economic development.

To begin with, those who advocate that democracy leads to economic growth hold the view that the wealthiest countries in the world are democracies. One of the earliest instances of this position is Adam Smith's Wealth of Nations postulations. Smith argued that the existence of political liberalism was a necessary condition for the operation of the market, which he considered the engine of efficiency and economic growth (Ake, 2000:76). For Smith, the government that governs least, govern best; minimal government is more conducive to individual freedom, competition, efficiency and prospect for growth. Accordingly, Lipset (1959) produced the most systematic scholarly argument regarding the correlation between democracy and economic development. For him, findings from a sample of countries studied from different regions of the world reveal a correspondence between democracy and economic development. For instance, he opined that economic development is associated with more education, assertiveness and a push for participation; it tempers the tone of politics and creates cross-cutting interests and multiple affiliations which facilitate democratic consensus-building and political stability. Conversely, Lipset thesis was to emphasize a causal relationship that flows from development to democracy rather than the other way round. In other words, countries with higher levels of development (typically measured as income) tend to also have higher levels of democracy. However, the exact specification of the relationship remains a matter of continued debate. As for Grossman and Noh (1988), democracy ensures accountability of rulers to the ruled with the result that rulers are motivated to allocate resources efficiently and productively in order to be allowed to stay in power. In similar vein, Dahl (I97I) argued also that democracy ensures that rulers limit their extraction of resources to what is optimal for growth and productivity. Olson (1991) contends that democracy commits the rulers to avoid pursuing selfish interests rather than policies which optimize growth and collective well-being.

Also, Mazrui (2002) opined that democratization and development share certain basic virtues such as popular participation, capacity expansion as well as freedom. Democratization is an independent variable that explains the level of economic development of any society. Furthermore, the idea of popular participation according to Adedeji (1997) is crucial to both democratization and development. In its comprehensive usage, popular participation is the empowerment of the people to involve themselves in 
the regulating structures and in designing policies and programmes that serve the interest of all, and contribute optimally to the development process. In the same vein, Zack-Williams (200I) argued that democracy is an essential requisite for economic development, in that it empowers the general population to control decision-making. As such, the governed are presumed to have all it takes to hold governments accountable by insisting on transparency, openness, and other measures of control. Thus the absence of these virtues is considered inimical to the pursuit of economic development. However, it is important to emphasize the point that while democratization may engender development, much of it depends to some extent on the context within which the analysis is carried out (Osaghae, 1995). Moreover, the impact of democratization could be a reflection of its time-spell as well as the depth of the democratization process itself. It could also be a spectral in the short run, giving the fact that development is a multidimensional concept.

According to the human development paradigm, democracy also engenders economic development. Development rests on 'the ability of people to help themselves and to influence the world (Sen, 1999b: 18). Such ability 'to do something not only for oneself but also for other member of society' is one of the elementary freedoms that people have reason to value... even among people who live very deprived lives in material terms (Dreze and Sen, 1995:106). For them, participation in designing the rules of the institutions which governs people's lives is thus an intrinsic component of human dignity, and the practice of democracy helps to achieve this objective. Furthermore, given the open-endedness and the multi-dimensionality of human beings, the practice of democracy enables us to specify the dimensions of human well-being which are worth being promoted. The role of public discussion and interactions in the emergence of shared values and commitments is essential in specifying a society's underlying values and in choosing the end of policies.

Thus, democracy plays a constructive role in value formation. It clarifies and constructs a society's values and priorities, such as the values of social equity, tolerance, political pluralism. For instance, some existing statistical analysis has suggested that democracies are better at providing human development and other measure of human welfare (child mortality, health, education and gender equality); distribute the benefits of development, measured through income distribution or total calorie intake, and promote human capital formation through direct public expenditure on health and education, which in turn has a positive impact on growth (Baum et al, 2003; Blaydes et al, 20II; Norris, 20l2). However, in looking at the direct (practical) relationship between democracy and economic development, analyses show that democracies are no better than non-democracies, but they also show that democracies are not worse off (Przeworksi et al, 2000). In all, for democratic practice to lead to desirable outcomes from the human development perspective, the requirement of a minimum level of equality needs to be fulfilled, for a fair distribution of power is a basic requirement of democracy.

However, Bhalla (1994) offers a different approach to the relationship between economic development and democracy. He argued that democracy is a form of government strongly associated with freedom, and proceeds to test the relationship between economic development and freedom (both political and economic) rather than the relationship between democracy and economic development. He contends that because they did not control for economic freedom, past studies may not have estimated appropriately the relationship between economic development and political freedom. He hypothesizes that freedom is conducive to greater economic development, which in turn leads to greater freedom also. Bhalla further opined that 'no matter how freedom is measured, and no matter how welfare change is defined, there is a strong and positive relationship between the two' ( $p$, 6). On the other hand, there are those who subscribe to the idea of endogenous democratization that posits that economic development causes democracy (Boix and Stokes, 2003). They argue that the changes brought about by higher levels of economic development merely enhance the probability that new democracy will survive (see Przeworski et al, 2000). In this case, many other factors may explain the advent of democracies across countries, but once it is established, the probability of its survival increases in countries with higher levels of economic development. In either case, development is seen as a key driver for sustainable democracy.

$\mathrm{Be}$ that as it may, since the end of the cold war, the successive 'waves' of democracy were accompanied by rising expectation about the tangible benefits of democratic rule for development. Citizens and policy makers in the developing countries that have democratized after 1974 (third wave democracies) and those that have done so after 1989 (fourth wave democracies) had expected that the stability and voice made possible under democratic rule would provide a better system for long term economic development. Despite this optimism around democracy, the life experiences of the people in Nigeria and Africa in general over the past two decades reveal any little empirical support for the 
argument that democracy is a better political system for promoting development. The lived experiences during the 'lost decade' in the 1980s in Africa, Latin America and the post-Communist new democracies in Eastern Europe created worries that democracy was not able to deliver economic benefits as expected. This occurrence therefore has today awakened the debate to seek for an alternative comprehensive approach to development and governance.

\section{Theoretical analysis of the relationship between demography, democratic governance and development}

Over the last two decades or more, issues of democratic transition, consolidation and quality of democracy have guided the analysis of political change in the developing world. Many empirical studies have shown that the gap between the reality and promise of democracy has been widening and there is the widespread perceptions that democratically elected government and officials are corrupt, incompetent, unresponsive and untrustworthy (Yaqub, 2007; Nwabueze, 2007). As such, over the last decade, a growing number of student of democratic studies have sought to develop means of framing and assessing the quality of democracy and identify ways to improve the quality of democratic governance (Chang et al, 20ll). However, since Nigeria's return to civilian rule in 1999, many Nigerians were of the strongest expectation that the process of democratization and democratic rule an would create an improved living standard for them through tackling the problems of poverty, unemployment, insecurity, infrastructure decay, diseases and poor sanitation. But available records on ground reveal a very dismal performance in terms of the democratic system delivering a better quality of life for the people.

Despite Nigeria's being the continent's most populous nation, the second largest economy in subSaharan Africa and currently the $8^{\text {th }}$ highest net oil exporter in the world, the country has consistently failed to transform these enormous economic potentials into viable and sustainable socioeconomic and political development. Preceding 1999 and afterwards, the country has consistently maintained a low ranking in the United Nations Human Development Index, which represent measures of a nation's living standard. For instance, more than 70 percent of Nigerians are classified as 'poor'-subsisting below the national poverty line, unemployment has grown from 12.3 percent in 2006 to 23.9 percent in $20 \mathrm{II}$ and has not abated till date, infant, child and maternal mortality rates remained one of the highest in the world, life expectancy is less than 52 years, inadequate infrastructure, budgetary allocation to the education and health sector is abysmally low ( 12 percent or less for education and 5 percent or less for health) since independence. Also, the 2010 Monitoring Report (GMR) of the United Nations Education, Scientific and Cultural Organization (UNESCO) revealed that 92 percent of Nigerians survive on less than US\$ 2 dollar daily, while 7I percent survives on less than US\$I dollar daily. These conditions have raised the question as to whether the practice of democracy can actually deliver better living standards for the people. This is contrary to the earlier strong rigour and enthusiasm held by the citizenry that a political environment guaranteeing human rights and rule of law would be more conducive to government accountability and probity and that 'popular based political processes would ensure the involvement of all in development effort. However, for one to interrogate these challenges with a view to proffering solutions on the way forward, it is important to look at the social forces which have given rise to them. To begin with, it is important to note that nation-state is built by exemplary men and women and by viable institutions that promote good governance and socio-economic development. Social phenomena are primarily the consequences of social processes and structures over which the individuals have little control and which run contrary to their desires (Washburn, 1982:31). To a large extent, individual's beliefs, values and wants are by themselves shaped by these structures and processes. Looking at the challenges associated with the practice of democratic governance in Nigeria and its impact on the standard of living of the people, the paper draws on historical analysis to examine issues relating to population and development question in the country. The paper argued that the nature of the social contract upon which democracy is structured is important for the analysis of everyday governance; noting that democracy cannot be fully understood without an analysis of how it responds to the concerns of the citizenry. As such, if we take the view that democracy is a process in which people not only seek to participate, but also through which to extract accountability from authority and to discipline politics and power in the interest of all, then of course, democracy and democratic struggles constitute a living and abiding part of any political system.

We cannot talk meaningfully about democratic governance if citizens cannot take active part in policy making and be confident that their active participation will help shape public policy. This is precisely the situation in Nigeria and other African countries today; a scenario described as a case of having choice-less democracies (Mkandawire, 1996). 
A situation in which policy on key issues in the economy and society or social processes are completely out of the realm of public discussion and belong to a technocratic policy elite very much tied to a transnational power structure basically organized around the Washington consensus with all its difficulties is anti-democracy. Up till the first decade of the $21^{\text {st }}$ century the economic policies and even social programmes pursued by many countries on the African continent are orchestrated, managed and controlled from either the former colonial masters or their partners, euphemistically called multinational corporations.

Public policy making in Nigeria is said to be a sphere captured by vested interests, many of which are still embedded in neo-patrimonial modes of accumulation, dependent on the state and on privileged access to state resources as a way of consolidating their power and influence. The nature of the Nigerian state from its origin was not to pay any serious attention to the problems of the subjects but to exploit the people and their resources to serve the goal and interest of the metropolis. This was later reinforced by the nature of political elites that emerged and whose goal was self-serving at the detriment of the masses and even the state. This fact clearly explains the framework upon which socioeconomic reforms particularly Structural Adjustment Programmes (SAPs) were being structured without taking into cognizance the cost implications it would have on the social welfare needs of the people. The unique feature of SAP is its rigorous austerity measures which include outright ban on some essential commodities even where no local alternatives exists, massive currency devaluation, subsidy removal, massive privatization, deregulation, steep cut in government expenditure, often disastrous for the social sector. The effect of the draconian SAP policies is that rather than address the problem of poverty, inequality and deprivation among the people, it exacerbated their living conditions resulting in more Nigerians living below the poverty line. Thus politics was emptied out of economic policy making and management of the country and the continent at large. This scenario represents one of the most undemocratic experiences in Nigeria since the 1990s whose consequences continued to play out in terms of the nature and form of policy making in the country.

Similarly, in 2004, as part of the strategies for achieving the MDGs in Nigeria, the Obasanjo administration enunciated the National Economic Empowerment and Development strategy (NEEDS), which was seen as a home-grown response to Nigeria's development challenges. It was a nationally coordinated programme of action aimed at laying a solid foundation for sustainable poverty reduction, employment generation, wealth creation and value orientation. The initiators of the programme assumed that it would lead to the social and economic transformation of Nigeria into a sustainable, modern and competitive and prosperous economy, thus positioning her as the largest economy in Africa and a major player in the global economy. The policy was further disaggregated to the state (SEEDS) and Local Government Levels (LEEDS). As a poverty reduction strategy, NEEDS was designed as a broad based market oriented policy that is private sector driven but with a human face.

However, a critical assessment of the NEEDS document showed that it is pure and simple a neoliberal market oriented reform, which has the endorsement of the World Bank and IMF. The NEEDS programmes was backed with the neo-liberal ideology "based on an unwavering belief in free markets. The framework focused on the promotion of ideals of mainframe capitalism with strong ideals for competitive market, private ownership, free trade, and export-led growth, strict controls on balance of payments, and deficits and drastic reductions in government social spending" (Aina, 20I2). Although, the NEEDS document seemingly avoids market fundamentalism by its focus on social charter and public sector reform, the absence of any policy mechanism for translating the rhetoric of poverty alleviation into concrete programmes of poverty alleviation and overemphasis on privatization, deregulation and liberalism cast it in the mould of past World Bank inspired Structural Adjustment Programme with its promotion of less government involvement in promoting the welfare needs of the people (Akimbo and Yinusa, 2007).

Furthermore, the federal government under the Jonathan Administration has formulated another policy to get Nigeria to be among the twenty top developed economies in the world by 2020. Again, the implementation of the latter policy is as much immersed in confusion and policy summersaults as the earlier ones which includes Gowon's National Accelerated Food Production Programme in 1972; Muritala/Obasanjo's Operation Feed the Nation in 1976; Shagari's Green Revolution in 1979; Babangida's People's Bank, Directorate of Food, Roads, and Rural Infrastructure (DFRRI), Nigerian Agricultural Land Development Authority (NALDA) established in 1986 and Family Support Programme (FSP); Abacha's Family Economic Advancement Programme (FEAP) in 1993; Obasanjo's National Poverty Eradication Programme (NAPEP) in 200I amongst others which have consistently failed to bring the people of Nigeria out of the hell of poverty. Basic among the myriad of problems associated with 
these poverty alleviation programmes is that they lack human face in their formulation and implementation process such that the people for whom the programmes were designed for never had input in their formation nor did the programmes addressed the issues of human development. The same fate has also befallen the use of development and rolling plans in the country.

These occurrences have raised the question of how the Nigerian nation would be able to build democratic governance if we emptied politics out of public policy for which the state holds a key responsibility. This is particularly significant since the state represent the system for the organization of power. The state, therefore is not only saddled with the task of developing and inculcating a set of norms which defines just economic exchanges and regulation, it also has the moral obligation of ensuring that "each is treated as he/she deserves, that he/she is free of all unjust and humiliating dependence, that he is joined to his fellows and to the group without abandoning his personality to them (Durkheim, 1958:72). It is the arena where the political aspect of social relations and politics for the exercise of power takes place, including the rationale for which people strives for political power either as a means in serving other aims, ideal or egoistic, or as 'power for its own sake; that is to enjoy the prestige feeling that power gives (Weber, 1958). Democratic governance becomes possible in a society only if political elites and their officials are prevented from usurping the political and legislative processes to promote their individual and other interests that are contrary to the needs of the majority of its citizens. It will therefore amount to mere wishful thinking to assume that one can build a society on a democratic footing without first having an effective and functioning state in place. Indeed, part of the democratic and development struggle in Nigeria and other African countries is how to build such a functioning and effective state that responds to the concerns of the common people as opposed to simply serving the interests of narrow class and elite group that often dominates its affairs (Mkandawire, 200I; Bangura, 2006; Edigheji, 20I0).

From the foregoing discourse, it is obvious that the pursuit of development is impossible when the people lack access to basic necessities of life and cannot enjoy freedom from servitude and exploitation. Likewise, democracy and human rights cannot thrive in economic adversity as socioeconomic deprivation perpetuate further deprivation Where there is passive lack of observance of political and human rights, economic rights will be severely undermined. Thus, the linkages between democratic governance, development and demography have significant implications on the strategy for the eradication of poverty which has consistently been undermined by corruption, poor governance and lack of political will to put the collective interests of the people above the interest of a privileged few whose objective is to plunder the reosurces of the state. This is where the question of lack of effective leadership becomes critical. The leadership structure in Nigeria has become one driven by the naked accumulation of the nation's resources for personal interest rather than a sense of service to transform the resources to make life better for the citizenry. The political elites see the state as the site for booty capitalism. The tendency to apply force ubiquitously in political and economic competition and also to appropriate surplus by force," with its psycho-cultural manifestations, remains a major obstacle to governance and development in the country (Acemoglu, 2003). These characters called the political elites have turned politics into a huge business enterprise, where competition rules and institutional processes are openly and crassly violated with impunity, and where regulators become active or vicarious collaborators in the grand robbery of democratic politics as a public interest project. As a result, the goal of politics as the pursuit of the res publica to advance people-oriented socioeconomic programmes has been relegated to the secondary considerations in outright violation of the spirit and letter of chapter II, Fundamental Objectives and Directive Principles of State Policy and the country's obligation under the African charter on Human and Peoples Rights and the United Nations Millennium Development Goals amongst others. Leading a nation involves making policies and finding solutions to problems, ensuring stability of the polity, and guiding society to prosperity. The absence of these attributes makes leadership and development difficult as it deepens the cleavages between the state and society. As such, the absence of a developmental state and democratic governance remains one of the primary causes of Nigeria's rising poverty and underdevelopment. Good governance which has been touted as a by-product of democracy that is expected to advance improvement in the welfare of the populace is yet to take root. In addition, the cost of maintaining the executive and legislative bodies at both the federal and state levels far exceed what is spent on capital votes in the nation's annual budgets. By and large the people are alienated from the mainstream of state policies and robbed of individual, community and national empowerment. Rather than being a solution and a platform for the resolution of the national question in Nigeria, democracy has become part and parcel of the problem. 


\section{Conclusions}

From the foregoing, one can conclude that there is an urgent need to engage a comprehensive approach to development for Nigeria. There are several avenues waiting to be explored for advancing development progress in the country. A critical factor to employ in this drive is the cultural reorientation of the people towards a desired national identity as well as prioritization of the welfare of the people. This implies that every parent has to inculcate in his/her children the spirit of honesty, hard work, thirst for acquisition of knowledge and upward mobility coupled with fairness in dealing with others. Besides, there is also the need for responsible parenthood in terms of number of children being born and the rearing and nurturing of offspring and dependants.

The national government should ensure that a credible and accurate population census is conducted every 10 years as recommended by the United Nations. Also, provision of vital registration centres in all the nook and crannies of the country should be vigorously pursued and made accessible for the issuance of certificates of births of new babies and death of individuals at such registration. Demographic Health Surveys should also be carried out every two years. These and other sources of information would yield accurate population figures for the country. Public enlightenment campaigns and the use of the mass media to address issues of fertility limitation, women's reproductive rights and provision of family planning services should be implemented vigorously at all levels of government in Nigeria. The delicate balance between population, resource availability and environmental sustainability must be borne in mind by all.

Furthermore, in the economic arena, government should keep abreast of the danger of the singleminded focus that has characterized development policies of the past and the present neo-liberal economic reforms. Government must take active role in monitoring the working of the economy through strengthening the markets and institutions of government, and figure out as it reaches each stage of development what the right mix of government and markets might be over time. Government should of necessity manage and regulate the overall economic framework, including ensuring supply of finance for the development of infrastructure, establish firmed legislation that guide corporate governance, provide social safety nets, maintain full employment, promote growth that limit inequality. Equally important is the need for government to engage an affirmative action programme targeted toward nation-building where all the ethnic groups in the country will have an equal stake in the Nigerian project and share in the fruits of development devoid of ethnic conflict.

Also equally important is the provision of treated portable water for the use of the general populace. At present many households in the urban and semiurban areas buy water sold to them by vendors who purchase same at boreholes or wells. The rich make boreholes in their houses and then pump the water into overhead tanks with machines operated by electricity with accompanying problem of power outages. Moreover, the water is hardly treated with chemicals for purification by the households' members before use. The provision of effective and efficient primary health services should be intensified as this would enhance physical and economic access to health care at the grassroots. This would limit the undue pressure on secondary and tertiary health facilities. Also Government officials should be made to utilize the health facilities within the country rather than going on medical tourism to other countries like India, South Africa, Spain, Germany and France.

With respect to the quality of housing, the simplification of the system for obtaining relevant documents for building houses would ensure speedy construction of buildings for domestic and commercial purposes. Once the housing need of the people are met at affordable costs and food supply is regular, then the average person would begin to think of how to improve his/her environment. Mortgage institutions in the country should also serve the poor. The welfare of the people should take priority over every other issue in the scheme of things for the development of the country. Sustainable development which allows the use of resources by the present generation of people while also leaving some resources for the future should be a target. The leadership must shun corruption and encourage best practices even as ICPC and EFCC cannot curb the practice if the elites are not committed to shun it.

Both the government and interested stakeholders should promote functional education as well as entrepreneurial training so that secondary and tertiary institution graduates can utilize those skills either as employees or employers of labour. Investment culture and savings attitude rather than consumption should be encouraged. Human capital development strategy should be part of the focus of rethinking development in Nigeria. Unutilized trained manpower especially among the youth must be deployed toward gainful ventures. The necessary tools/materials should be provided for the people who are engaged in productive ventures. There should also be the introduction of social security system that caters for the vulnerable members of society such as women, children, the unemployed, physically challenged and the elderly in order to 
cushion the effects of poverty. Such a scheme would ensure that there is security of life and property in the country and for all categories of people. In order to check the abuse of the scheme the biometric measurement of the recipients should be obtained and used. Finally, for development to begin to manifest in Nigeria, people must count economically, politically and socially. We must all determine to make Nigeria succeed and not allow our nationalistic disposition to become conterminous with the will, desires and agenda of the ruling elite especially where the state is held hostage by buccaneers as is lamentably the case of Nigeria.

\section{References}

Achemoglu, D. (2003) "Root Causes", a Historical Approach to Assessing the Role of

Institutions in Economic Development," Finance and Development Vol. 40 (2)

Adedeji, A. (1997) Popular Participation, Democracy and Development: Is there a Dialectical

Linkage? in Adedeji, A. and Onigu, O. (eds.)

Nigeria: Renewal from the Roots? The

Struggle for Democratic Development. ljebuOde: ACDESS.

(2006) Keynote address at EISA

Symposium, "Challenges for Democratic

Governance and Human Development in Africa", Wanderers Club, Illovo, Johannesburg,

South Africa, 8-10 November.

Adekola, A.A. (2010) Democratic Development in Nigeria since Independence: Challenges and

Prospects. Ibadan: College Press and Publishers Ltd.

Ake, Claude. (1996) Democracy and Development in Africa. Washington, D.C.: Africa Books

Collective Publishers-------------- (2000) The

Feasibility of Democracy in Africa. Senegal, Dakar: CODESRIA

Akimbo, A.E. and D.O. Yinusa (2007) "Nigeria in the Twenty-First Century: The Journey so far and Outlook for the Future", Paper Presented at the International Conference on Nigeria in the Twenty-First Century: Issues and Challenges, Organized by the Faculty of Business

Administration, Obafemi Awolowo University, Ile-Ife, Nigeria.

Alex De Shebinin and George Martine (2007) "Urban population development and environment

dynamics", Policy paper 3, Committee for International Cooperation in national research in Demography (CICRED). Paris.

Amadou, Diallo and Quentin Wodon (2007) Demographic transition smaller family size and basic infrastructure needs in developing countries. Economic Bulletin, Department of
Economics, Vanderbilt University, Nashville

Anrudh, K. Jain. (2008) "A Tryst with Destiny: Demography can help realize the Dream"

Presented at the Fourth Sat Paul Mittal Memorial Lecture delivered at the Jawaharlal Nehru

University, New Delhi. September $15^{\text {th }}$.

Asian Development Bank (2004) "Poverty in Asia: Measurement, Estimates and Prospects". Manila

Axel, Hadenius. (1992) Democracy and Development. London: Cambridge University Press.

Azinge, E. (2004) "The Nigerian State and Conflict Management in the Nascent Democratic

Project" in Agagu, A. A. and Ola, R. F. (eds.) Development Agenda of the Nigerian State. Ibadan: FIAG Publishers.

Bangura, Yusuf. And George, Larbc (2006) (Eds.) Public Sector Reforms in Developing

Countries. Hampshire: Palgrave Macmillan

Baum, M. A. and Lake, D. A. (2003) The Political Economy of Growth: Democracy and Human Capital. American Journal of Political Science 47 (2): 333-347.

Blackburn, James. and Jereme, Holland. (1998) (eds.) Who Changes? Institutionalizing

Participation in Development. London: Intermediate Technology Publication.

Blaydes, L. and Kayser, M. A. (20II) Counting Calories: Democracy and Distribution in the

Developing World. International Studies Quarterly 55: 887-908.

Central Intelligence Agency (CIA) (200I) Long-term Global Demographic Trends: Reshaping the Geopolitical Landscape. Langley, VA, July.

Chang, Yu-Tzung., Yun-Han Chu and Min-Hua Huang (201 I) Procedural Quality Only?

Taiwanese Democracy Reconsidered. International Political Science Review.

Chiazor, I. A. and Egharevba, M. E. (2013) Money Politics and Good Governance in Nigeria, International Journal of Social Sciences and Humanities Review, Vol. 4 (2): I22-I 36.

Chirot, D. (1997) Social Change in the Twentieth Century. New York: Harcourt Brace Jovanovich.

Dahl, A. Robert (I97I) Polyarchy: Participation and Opposition. New Haven: Yale University Press.

(1989) Democracy and its Critics. New Haven, CT: Yale University Press.

Dennis Guolet (197I) The cruel choice: A new concept in the theory of development. New York: Antheneum.

Dudley, Seers (1969) "The meaning of development", paper presented at the $\mathrm{II}^{\text {th }}$ World 
Conference of the Society for International Development. New Delhi: 3

Dreze, Jean and Amartya, Sen. (1995) India: Economic Development and Social Opportunity. Delhi: Oxford University Press. (2002) India

Development and Participation. Delhi: Oxford University Press

Durkheim, Emile. (1958) Professional Ethics and Civil Morals, Cornelia Brookfield, Trans. New York: The Free Press.

Dye, Thomas. (1975) Power and Society: An Introduction to the Social Sciences. California: Duxbury Press.

Egharevba, M. E., Iruonagbe, C. T., Azuh, D. E. and Chiazor, I. A. (2016) Poverty, Inequality and Human Development in Nigeria: Appraising the Non-Attainment of the MDGs, Ife PsycholoGIA, Vol. 24 (I): 27-46.

Egharevba, M. E. and Chiazor, I. A. (20/3) Democratic Governance and Human Development Sustainability in Nigeria, Crawford Journal of Business and Social Sciences, Vol. 3 (2): III-| 48.

(20/3) Protecting Women Against

Domestic Violence: Current Issues and Future Directions, Journal of Gender and Behaviour, Vol. II (2): 5653-5662.

Edewor, P. (2008) "Cultural values and successful census operation", in Oyekanmi, f. D. and

Ogunlade, P. B. (eds.) Appraisals of the preparation for the 2006 population and housing

census of Nigeria. Lagos: Department of Sociology, University of Lagos, Chapter 9.

Edigheli, Omano. (2010) (ed.) Constructing a Democratic developmental State in South Africa.

Pretoria: Human Sciences Research Council.

Ersson, S. and Lane, J. E. (1996) 'Democracy and Development: A Statistical Exploration', in

A. Leftwich (ed.) Democracy and Development. Cambridge: Polity. 45-73.

Fausta, $O$ and Silvani, S. (2016) Demographic Pressure and Development in a Gender Perspective:

A Focus on Sub-Saharan Africa, African Population Studies, Vol. 30 (2): 2806-2820.

Feng, Y. (200I) Politics and Development in Nigeria. London: Spectrum Books.

Fukuyama, F. (1992) The End of History and the Last Man. London: Hamish Hamilton.

Grace, C. and Andrian, G. (2016) Keeping or Catching Up? Population Dynamics and Education in Africa, African Population Studies, Vol. 30 (2): 2575-2584.

Grossman, H. I. and Noh, S. I. (1988) Proprietary Public Finance, Public Competition and Regulation. IMF Seminar Series No 8: I
Handelman, Howard. (2006) The Challenge of Third World Development ( $4^{\text {th }}$ Ed.) New Jersey:

Prentice Hall

Huntington, P. Samuel (1991) The Third Wave Democratization in the Late Twentieth Century. Norman: University of Oklahoma Press.

John Bongaarts (2005) "The causes of stalled fertility transactions", Policy research Division working paper. New York: Population Council.

John, D. Rockefeller. (1952) Address on the foundation of The Population Council.

Kaufmann, D., A. Kraay and M. Mastruzzi (2005) Government Matters IV: Governance Indicators for 1996-2004. www.worldbank.org/governace/kkz 2004/mc_countries.

Kitching, Gavin (1982) Development and underdevelopment in historical perspective: Populism,

nationalism and industrialization. London and New York: Methuen.

Kofele-Kale. (2006) The International Law of Responsibility for Economic Crimes: Holding

States Officials Individually Liable for Acts of Fraudulent Enrichment. Hampshire, England:

Ashgate Publishing Ltd.

Lawal, Gbenga (2007) Corruption and development in Africa: Challenges for political and economic change, Human and Social Sciences Journal 2 (I).

Macionis, J. John. (200I) Sociology. (8 ${ }^{\text {th }}$ Edition) New Jersey: Prentice Hall.

Mary Kent and Carl Haub (2005) The global demographic Divide. Population Bulletin, vol. 60

(4) December.

Mazrui, A. (2002) "Nigeria's Search for Good Governance and National Development: Dilemma of Policy and Leadership" in Lame, I.Y. and Dabin, H. (Eds.) Democracy and Governance and National Development in Nigeria: Actualizing the People's Mandate. Ibadan: Spectrum Books.

Mkandawire, Thandika. (2002) "Thinking about Development States in Africa," Cambridge Journal of Economics 25 (3). (1999) "Crisis Management and the making of choiceless Democracies", in Joseph Richard (ed.) State, conflict and democracy in Africa. London: Lynne Rienner.

Monshipouri, M. (1995) Democratization, Liberalization and Human Rights in the Third World.

London: Lynn Reinner.

Morrick, T. (200I) Population and Poverty in Households: A Review of Reviews in Birdsall, N., 
Kelley, A.C. and Sinding, S. W (eds.) Population Matters: Demographic Change, Economic Growth and Poverty in the Developing World. New York: Oxford University Press.

Morris, Morris, David (1980) The Physical Quality of Life Index , Development Digest I: 95-

109.

National Bureau of Statistics (20I2) 2010 poverty and income distribution report. Abuja.

National Demographic and Health Survey (2008) Demographic and Health Survey Fact Sheet. National Population Commission. www.population.gov.ng

National Planning Commission (2005) NEEDS. Abuja.

National Population Commission (2009) 2006 Population and housing census of the Federal

Republic of Nigeria National and state population and housing table, volume

I, National Population Commission, Abuja, August.

National Research Council (1986) Population Growth and Economic Development: Policy

Questions. Washington D.C.: National Academy Press

Norris, Pippa. (20/2) Making Democratic Governance Work: The Impact of Regimes on

Prosperity, Welfare and Peace. Cambridge: Cambridge University Press

Nnoli, O. (1995) Ethnicity and Development in Nigeria. London: Auebury

Nnorom, C. P. (2008) Appraisals of the census officials: Lessons learnt and prospects",

Oyekanmi, F. D. and Ogunlade, P. B. (eds.) Appraisals of the preparation for the 2006

population and housing census of Nigeria. Lagos: Department of Sociology, University of Lagos, chapter II.

Nnorom, C. P and Kunnuji, Michael (2006) "Crisis of numerical supremacy and

governance in a plural polity: The Nigerian case", in Oyekanmi, F. D and Soyombo, O (eds.)

Society and Governance: the quest for legitimacy in Nigeria. Lagos: Department of

Sociology, University of Lagos and Friedrich Ebert Stiftung, Lagos, Nigeria,

Nwabueze, NduKaeze (2007) "Nigeria: Exogeneity and the deepening of the crisis of

underdevelopment and democratization", in

Oyekanmi F. D and Soyombo O. (eds.) Society

and Governance: the quest for legitimacy in

Nigeria. Lagos: Department of Sociology,

University of Lagos and Friedrich Ebert Stiftung, Lagos, Nigeria, chapter 3.

Obono, O. M (2002) "Rethinking the Nigerian population policy: Toward a multicultural perspective", in Abanihe, U. C, Isamah, A. N and Adesina, J. $\mathrm{O}$ (eds.) Currents and

Perspectives in Sociology, Lagos: Malthouse Press Limited

Olson, M. Jr. (199I) "Autocracy, Democracy and Prosperity", in Richard, J. Zeckhauser (ed.)

Strategy and Choice. Cambridge, Mass.: MIT Press: |3|-57.

Omotola, J. S. (2006) "No Democracy, No Development or Vice-Versa", in Saliu, A. A. et al (Eds.) Democracy and Development in Nigeria. Lagos: Concept Publishers.

O'Neil, Brain. (2008) "Population and Climate Change: Relationships, Research and

Responses" Presentation at Woodrow Wilson International Centre for Scholars, Washington,

D.C. February $20^{\text {th }}$.

Organization for Economic Development and Cooperation (OECD) (I999) Guideline for Gender

Equality and Women Empowerment in Development Cooperation, Paris: OECD

Publications. II-36.

Osaghae, E. E. (1995) Democratization in Africa: Faultering Prospects, New Hopes. Journal of Contemporary African Studies 17 (I).

Oyefara, John. L. (2008) "Census Data, Socioeconomic Planning and sustainable development in Nigeria", in Oyekanmi, F. D and Ogunlade, P. $B$ (eds.) Appraisals of the preparation for 2006 population and housing census in Nigeria, Lagos: Department of Sociology, University of Lagos, Chapter 4.

Oyekanmi, F. D (1992) "Problems of obtaining accurate population counts for development planning in Nigeria: The Census controversy", in Nwabueze, N. and Oyekanmi, F. D (eds.)

Social Problems and social policy in Nigeria, Lagos: Osko Associates, chapter 9.

(2009) "Current themes in population studies", in Soyombo, O and Olurode, L.

(eds.) Sociology for Beginners, Lagos: John West Publications: 165-190. (2008) "Linkages between census data and sustainable development: MDGs,

NEEDS and the population and housing census 2006", in Oyekanmi F. D and Ogunlade, P.

B (eds.) Appraisals of the preparation for the 2006 population and housing census in

Nigeria, Lagos, department of Sociology, University of Lagos, chapter 3.

Population and Reference Bureau (20I I) The World's women and girls 20I I data sheet, PRB,

Washington, D.C, USA. 
Rachel Nugent and Babara Seligman (2003) How demographic change affect development in the $2 I^{\text {st }}$ Century Initiative, Technical paper. US Department of State, US Agency for International Development Strategic Plan FV2004-2009), Security, Democracy, Prosperity, August.

Richard, Brinkman (1995) "Economic growth versus economic development: Toward a conceptual clarification", Journal of Economic Issues 29: II 7I-II 88.

Rodney, W. (1972) How Europe Underdeveloped Africa. London: Bogle- Louverture

Sen, K. Amartya (1990) "Development as Capacity Expansion", in Griffing, K. and Knight, J.

(Eds.) Human Development and International Development Strategy for the 1990s. New York: Macmillan.

(1999) Development as Freedom. Oxford: Oxford University Press.

(1999a) "Democracy as Universal

Value" Journal of Democracy 10 (3) : 3-I7

(1999b) Development as Freedom.

Delhi: Oxford University Press

Timmer, P. (2008) The Structural Transformation and the Changing Role of Agriculture in Economic Development: Empirics and Implications. Available from:

Prospects: The 2006 Revision, Highlights. Working Paper No ESA/P/WP.202.

Washburn, P. C. (1982) Political Sociology: Approaches, Concepts and Hypotheses, New Jersey: Prentice-Hall.

Weber, Max. (1958) "Politics as a Vocation", in From Max Weber: Essays in Sociology, H.H.

Gerth and C.W. Mills (Eds.) New York: Oxford University Press.

Wesley, Carrington., Jim, Debuse and Hee Jin, Lee (2008) The Theory of Governance and Accountability. The University of lowa, Centre for International Finance and Development

Williams, Easterly (2003) "The political economy of growth without development: A case study

of Pakistan", in Dani Rodrik (ed.) In search of prosperity: Analytical narratives on Economic Growth. Princeton, N. J: Princeton University Press.

Williamson, J. G. (200I) "Demographic Change, Economic Growth and Inequality", in Birdsall, N., Kelly, A.C. and Sinding, S. W. Population Matters: Demographic Change,
Http://iisdb.stanford.edu/pubs/22 I33/Timmer_we ndt_lecture.pdf.

Todaro, M. P. and Smith, S. C. (20II) Economic Development ( $6^{\text {th }}$ edition.) London: Longman.

UNDP (2007) Governance for Sustainable Human Development, A UNDP Policy Paper.

UNDP (1992) Human Development Report. New York: Oxford University Press

UNDP (2010) Human Development Report: The Real Pathway to Human Development. Basingstoke: Palgrave Macmillan.

UNESCO (1996) Working Group on International Statistical Programmes and Coordination.

UN Social Indicators. New York. April I6-19.

United Nations (2006) Frequently Asked Question on Human Rights-Based approach to

Development Cooperation, New York: Office of the UN High Commissioner for Human

Rights.

United Nations (2009) World population prospects: the 2008 revision volume II: Sex and age

distribution of the world population. United Nations Economic and Social Affairs,

Population division: 694-695.

United Nations $(2010 \mathrm{c})$ The Millennium Development Goal report 2010, New York.

UN Department of Economic and Social Affairs Population Division. World Population on

Economic Growth and Poverty in the Developing World. New York: Oxford University Press.

World Bank (1989) "Sub-Saharan Africa: From Crisis to Sustainable Growth: A Long-term

Perspective Study." Washington, D.C.: World Bank.

World Bank Commission on Growth and Development (2008) "New Global Trends," The

Growth Report: Strategies for Sustained Growth and Inclusive Development. Washington,

D.C: World Bank. May.

Yaqub, Nuhu (2007) "Society and governance: the quest for legitimacy in Nigeria" in Oyekanmi

F. D. and Soyombo, $\mathrm{O}$ (eds.) Society and Governance: the quest for Legitimacy in Nigeria.

Lagos: Department of Sociology, University of Lagos and Friedrich Ebert Stiftung, Lagos,

Nigeria, chapter 2.

Zack-Williams, A. B. (200I) No democracy, No Development: Reflections on Democracy and Development in Africa. Review of Africa Political Economy 28 (88). 